\section{HIV-1 seroprevalence in the general population of Salvador, Bahia State, Northeast Brazil}

\author{
Soroprevalência do HIV-1 na população geral de \\ Salvador, Bahia, Brasil
}

\author{
${ }^{1}$ Instituto de Saúde Coletiva, \\ Universidade Federal da \\ Bahia, Salvador, Brasil. \\ 2 Centro de Pesquisas \\ Gonçalo Moniz, Fundação \\ Oswaldo Cruz, Salvador, \\ Brasil. \\ 3 Escola Bahiana de \\ Medicina e Saúde Pública \\ Fundação Bahiana para \\ o Desenvolvimento das \\ Ciências, Salvador, Brasil. \\ 4 Instituto Oswaldo Cruz, \\ Fundação Oswaldo Cruz, \\ Rio de Janeiro, Brasil. \\ Correspondence \\ I. Dourado \\ Instituto de Saúde \\ Coletiva, Universidade \\ Federal da Bahia. \\ Rua Basílio da Gama s/n, \\ Campus do Canela, Salvador. \\ BA 40110-040, Brasil. \\ maines@ufba.br
}

\begin{abstract}
To estimate HIV-1 seroprevalence in the general population of Salvador, Bahia, Brazil, we conducted a cross-sectional survey of 3,437 residents from 1998 to 2000. Subjects were drawn from 30 sentinel areas representing a wide range of living conditions. Plasma samples were screened for HIV-1 antibodies by ELISA and confirmed by immunofluorescent assay. Subtype determination by HMA was performed after proviral DNA amplification. Phylogenetic analysis using parsimony was performed with the neighbor-joining method. Overall HIV-1 seroprevalence was 0.55\% (19/3,446): 0.8\% for men and 0.36\% for women. Seroprevalence was higher in the 31 45-year age group (1\%) and among persons with family income less than twice the minimum wage (0.78\%) as compared to $0.33 \%$ for the higher income group. Syphilis was detected in $37 \%$ of HIV seropositive individuals. Phylogenetic inferences identified 10 samples as subtype B in the env region and 2 samples with Benv/Fgag/Fpol and Fenv/Bgag. Age $\geq 30$ years, male gender, and income $\leq 2$ times the minimum wage were identified as risk factors for HIV-1 infection. Extrapolating the proportion of seropositive individuals to Salvador, the number of HIV-1 infected individuals was estimated at 13,750.
\end{abstract}

HIV-1; HIV Seroprevalence; Cross-sectional Studies

\author{
Inês Dourado 1 \\ Craig A. Milroy 1 \\ Marco Antônio Gomes Mello 2,3 \\ Geraldo Argolo Ferraro 2,3 \\ Humberto Castro-Lima Filho 2,3 \\ Monick Lindenmeyer Guimarães 4 \\ Mariza Gonçalves Morgado 4 \\ Maria Gloria Teixeira 1 \\ Maurício L. Barreto 1 \\ Bernardo Galvão-Castro 2,3
}

\section{Introduction}

The acquired immunodeficiency syndrome (AIDS) and human immunodeficiency virus (HIV) were described and isolated, respectively, in 1981 and 1983 1,2. In Brazil, the first AIDS case was retrospectively identified in 1980 in the city of São Paulo, in the Southeast region of the country. Since then, AIDS incidence has increased in all 27 Brazilian States, but AIDS cases are still concentrated mainly in the Southeast. In 2003, AIDS incidence was 18.2 cases per 100,000 inhabitants ${ }^{3}$. Brazil is now one of the most heavily affected Latin American countries, with an estimated 600 thousand people living with HIV/AIDS. The HIV epidemic in Brazil has followed global trends: transmission was initially concentrated in men who have sex with men, then spread to injection drug users (IDU) in a second phase, and is currently marked by increasing spread among heterosexuals, who constituted the majority (57\%) of all sexually transmitted AIDS cases reported in 2003. Transmission is also increasing among the impoverished and illiterate segments of society, and is spreading from large urban areas to smaller cities $(<50,000$ inhabitants $) 4,5,6$. An estimated 16,410 pregnant women $(0.429 \%)$ aged 15-34 years are infected with HIV 7.

Salvador, capital of Bahia State (Northeast Brazil), has approximately 2.5 million inhabitants, the majority black or mixed-race $(80 \%)$. Although AIDS incidence in Bahia is lower than 
in the Southeast, the epidemic is an important public health problem in the Northeast. Since the ethnic and socio-demographic characteristics of Salvador are similar to those of large African or Haitian cities, HIV was initially expected to spread mainly through heterosexual contact, but the trend in the epidemiological profile has been similar to that observed in Southeast Brazil 8.

Although HIV-1 subtypes B, F, A, C, and recombinant $\mathrm{B} / \mathrm{F}$ and $\mathrm{B} / \mathrm{C}$ viruses have been identified in Brazil 9, only subtypes B and $F$ have been described in Salvador 10. Thus far, HIV prevalence has been estimated through surveys in specific population groups. This study reports the HIV-1 prevalence in a general population sample from Salvador and its association with various sociodemographic variables and describes the HIV subtypes circulating in the city.

\section{Methods}

This research is part of a larger ongoing project to estimate the incidence and prevalence of serological markers of main infectious agents among residents of certain intra-urban spaces called "sentinel areas" in the city of Salvador, Bahia, Northeast Brazil 11. The strategy was adopted in Salvador to evaluate the population's health visà-vis key infectious agents 1 .

The sampling method has been described in detail elsewhere 11. In short, the study population was drawn from a spatial sample of 30 sentinel areas representing a wide range of living conditions. Each sentinel area, in turn, consisted of two or more adjacent census tracts with similar income levels and basic sanitation coverage. A census in the selected sentinel areas identified an estimated 68,749 residents; 3,446 of whom were surveyed according to a simple random sampling procedure without replacement 12. Data on income, sanitation, and population density were provided by the Instituto Brasileiro de Geografia e Estatística (IBGE) 13 and data on area of residence, gender, age, income, and schooling were collected from May 1998 to July 2000 by questionnaire.

Other important HIV risk factors were not assessed because the main project addressed environmental and demographic factors relevant to infectious agents in general. After obtaining signed consent, $10 \mathrm{ml}$ of blood were obtained from each individual, using ethylenediamine tetraacetic acid (EDTA) as an anticoagulant. For children, blood was collected after signed consent from the mother or guardian, using appropriate equipment for the child's age. Plasma was separated by centrifugation, and both plasma and blood cells were stored at $-20^{\circ} \mathrm{C}$. Samples were anonymized prior to laboratory analysis. HIV prevalence was estimated retrospectively, anonymously, and unlinked. Therefore, it was not possible to collect other important risk factors. The research protocol was approved by the Research Ethics Committee of the Centro de Pesquisas Gonçalo Moniz, Fundação Oswaldo Cruz.

\section{Laboratory methods}

\section{- Serology}

Plasma was screened for HIV antibodies by ELISA (Ortho Diagnostics EIA, Rochester, USA) and confirmed by indirect immunofluorescence (Bio-Manguinhos, Fundação Oswaldo Cruz, Rio de Janeiro, Brazil), following the manufacturer's recommendations. Treponema pallidum infection was tested by reactivity to nontreponemal cardiolipin using the Venereal Disease Research Laboratory test (Laborclin, Paraná, Brazil) and confirmed by indirect immunofluorescence (FTA, Hoechst/Behring, Germany). Hepatitis C virus antibodies, hepatitis B core antibodies, and hepatitis B surface antigens were detected by ELISA (Roche, Basel, Switzerland).

\section{- Molecular studies}

After DNA extraction and PCR amplification, env and gag genes were evaluated by heteroduplex mobility assay to determine HIV-1 subtype 14 . Restriction fragment length polymorphism (RFLP) was used to identify B and B" HIV-1 subtypes 15 . PCR amplification of $e n v$ and pol regions was performed as previously described 16,17, and the products were direct-sequenced by an automated fluorescent method (ABI DNA Sequencer 310 or 3100 ). The DNASTAR package was used to edit the sequences, and the alignment of the edited sequences and reference HIV-1 subtypes from the Los Alamos database was obtained by Clustal X 18. Phylogenetic inferences were based on PAUP4 (neighbor-joining method), and the Kimura two-parameter algorithm was implemented for the estimation of evolutionary distances. The HIV-1 envelope sequences described in this study were assigned GenBank accession numbers (AY928535-AY928548).

\section{Data analysis}

Univariate associations were explored with 2x2 tables, and odds ratios (OR) and $95 \%$ confidence intervals $(95 \% \mathrm{CI})$ were used to measure the association between selected variables and HIV-1 infection 19. Cutoff points were determined by 
examining the frequency distribution of each variable. Although four different age strata were initially defined to evaluate age-based prevalence trends, the best single cutoff point was found to be 30 years. The other variables evaluated were: education ( $<4$ years of schooling); family income $(\leq 2.0$ times the monthly Brazilian minimum wage, or approximately US\$100 per month at the time of our survey), and gender (male). For preschoolers, we applied the mother's educational level. Multiple logistic regression was subsequently used to compute adjusted odds ratios, and Pearson's goodness-of-fit test and associated $\chi^{2}$, along with profile analysis and both Pearson and deviance residuals, were used to check model specification. The cluster effect of the sample procedure was adjusted in the logistic regression model. Statistical analyses were performed with Epi Info version 6.0 (Centers for Disease Control and Prevention, Atlanta, USA) and Stata version 7.0 (Stata Corporation, College Station, USA).

\section{Results}

The study population consisted of 1,491 men (43\%) and 1,946 women (56\%), ranging from less than 1 to 99 years of age. Overall HIV-1 prevalence was $0.55 \%(19 / 3,446$; 95\%CI: $0.34-0.88)$. Sixty-three percent of the seropositive individuals were men, and the majority (68\%) earned twice the minimum wage or less, including five of the six women with income data (Table 1). No one younger than 9 years and no woman younger than 17 years or older than 50 years was infected. We determined subtypes for 15 of the 19 HIV-1 positive samples: 11 in the env region, 8 in gag, and 6 in pol. Seven samples were subtyped in both the env and gag regions; 5 of them were subtype $B$ in both regions and 2 presented discordant subtypes (Benv/Fgag/Fpol and Fenv/Bgag) (Table 1). No sample presented the typical "Brazilian B” pattern in the gp120 V3 loop. Syphilis seroreactivity was positive in 7 of the 19 HIV seropositive subjects (37\%). None of the participants was positive for hepatitis antibodies or surface antigens.

Table 1

Socioeconomic and laboratory profiles of the 19 HIV-positive individuals. Salvador, Bahia, Brazil, 1998-2000.

\begin{tabular}{|c|c|c|c|c|c|c|c|}
\hline Gender & Age & $\begin{array}{l}\text { Monthly income } \\
\text { (times the } \\
\text { minimum wage) }\end{array}$ & $\begin{array}{l}\text { Schooling } \\
\text { (years) }\end{array}$ & env & $\begin{array}{l}\text { ubtyp } \\
\text { gag }\end{array}$ & pol & Syphilis \\
\hline \multirow[t]{7}{*}{ Female } & 17 & $\leq 2$ & $<4$ & $\star \star$ & $\star \star$ & $\star \star$ & Negative \\
\hline & 20 & $>2$ & $\geq 4$ & B & B & B & Negative \\
\hline & 30 & & $\geq 4$ & nd & nd & nd & Negative \\
\hline & 33 & $\leq 2$ & $<4$ & $B$ & $B$ & $\star \star$ & Negative \\
\hline & 40 & $\leq 2$ & $<4$ & nd & nd & nd & Positive \\
\hline & 43 & $\leq 2$ & $<4$ & $\star \star$ & $\star \star$ & $B$ & Positive \\
\hline & 45 & $\leq 2$ & $\geq 4$ & $B$ & $\star \star$ & $\star \star$ & Negative \\
\hline \multirow[t]{12}{*}{ Male } & 9 & $\leq 2$ & $<4$ & nd & nd & nd & Negative \\
\hline & 19 & $>2$ & $<4$ & nd & nd & nd & Negative \\
\hline & 27 & $>2$ & $\geq 4$ & $\mathrm{~F}$ & $B$ & $\star \star$ & Negative \\
\hline & 29 & $\leq 2$ & $<4$ & B & $\mathrm{F}$ & $\mathrm{F}$ & Negative \\
\hline & 30 & $\leq 2$ & $<4$ & B & ** & ** & Positive \\
\hline & 30 & $\leq 2$ & $\geq 4$ & $B$ & $B$ & B & Positive \\
\hline & 41 & $\leq 2$ & $<4$ & B & $\star \star$ & $\star \star$ & Negative \\
\hline & 43 & $\leq 2$ & $<4$ & $\star \star$ & $\star \star$ & $\star \star$ & Negative \\
\hline & 45 & $>2$ & $\geq 4$ & B & B & B & Positive \\
\hline & 45 & $>2$ & $\geq 4$ & $\star \star$ & B & $\star \star$ & Positive \\
\hline & 54 & $\leq 2$ & $\geq 4$ & B & $\star \star$ & $\star \star$ & Negative \\
\hline & 68 & $\leq 2$ & $\geq 4$ & B & B & B & Positive \\
\hline
\end{tabular}

nd $=$ not done (insufficient sample volume for conducting PCR).

* One monthly minimum wage at the time of our survey $=$ US\$ 50.00 (approx.).

** Negative (PCR result was negative). 
In the univariate analyses, the highest prevalence rates were in the 30-50-year age bracket, lower-income individuals, and men (Table 2). Prevalence rates in the 16-30 and 31-50-year brackets were 6 and 8 times higher, respectively, than in the 0-15-year group. However, the 95\% confidence intervals were wide and imprecise. Although prevalence in men $(0.81 \%)$ was nearly twice that of women $(0.36 \%)$, the small number of seropositive individuals was insufficient to assess correlation with gender. Infection rates were higher in men of all age groups, increasing from $0.23 \%$ to $1.11 \%$ up to 51 years old, reaching $1.23 \%$ for men over 51 (Figure 1). In contrast, infection rates in women peaked in the 31-50year group and fell to $0 \%$ in the group over 51 . Prevalence was similar for both levels of education (Table 2).

Odds ratios for the association between HIV infection and age, gender, and income increased and became more significant when adjusted by multiple logistic regression (Table 3). The multivariate model accounted for a small portion of the overall variance (adjusted pseudo- $\mathrm{R}^{2}=0.07$ ), but was well-specified (Pearson's $\chi^{2}=14.3, \mathrm{p}<$ 0.22).

\section{Discussion}

This is the first study in Latin America to estimate HIV seroprevalence and characterize HIV subtypes in the general population. We estimated an overall HIV-1 prevalence of $0.55 \%$ in our large representative sample of individuals of all ages (6 months to 99 years) from thirty sentinel surveillance areas in Salvador. This profile corresponds to the World Bank criteria 20 for a "low level” epidemic. However, previous identification of prevalence higher than $5 \%$ in specific highrisk groups (IDU) 21 suggests that the epidemic should be classified as "concentrated".

The lack of urban cohesiveness and tendency towards unstructured urban growth in many Latin American cities precludes surveillance by traditional means. As a result, several studies in Latin America have monitored health problems in urban "sentinel areas" created and selected according to predefined criteria. This strategy was adopted in Salvador to facilitate the evaluation of population health interventions 11,22. Results from these studies have demonstrated the strategy's great potential and timeliness, facilitated epidemiological surveillance in the city, enhanced the analysis of public health issues, and stimulated the development of special epidemiological studies.

The estimated prevalence in our general population sample for the 15-49 years age-group

Univariate analysis of factors related to human immunodeficiency virus type 1 (HIV-1) infection.

Salvador, Bahia, Brazil, 1998-2000.

\begin{tabular}{|c|c|c|c|c|c|c|}
\hline Variable & $\mathbf{N}$ & Positive (\%) & $95 \% \mathrm{Cl}$ & OR & $95 \% \mathrm{Cl}$ & $p$ value \\
\hline \multicolumn{7}{|l|}{ Age (years) } \\
\hline$<1-15$ & 866 & 0.12 & $0.006-0.75$ & 1.00 & & \\
\hline $16-30$ & 1,193 & 0.67 & $0.31-1.37$ & 5.98 & $0.75-129.92$ & 0.051 \\
\hline $31-50$ & 927 & 0.87 & $0.40-1.77$ & 7.71 & $0.97-167.56$ & 0.022 \\
\hline$\geq 51$ & 439 & 0.46 & $0.08-1.83$ & 4.05 & $0.28-115.11$ & 0.256 \\
\hline \multicolumn{7}{|l|}{ Gender } \\
\hline Female & 1,946 & 0.36 & $0.16-0.78$ & 1.00 & & \\
\hline Male & 1,491 & 0.81 & $0.44-1.44$ & 2.25 & $0.81-6.75$ & 0.066 \\
\hline \multicolumn{7}{|c|}{ Schooling (years) } \\
\hline$\geq 4$ & 1,530 & 0.59 & $0.29-1.16$ & 1.00 & & \\
\hline$<4$ & 1,892 & 0.53 & $0.27-1.00$ & 0.90 & $0.33-2.50$ & 0.496 \\
\hline \multicolumn{7}{|c|}{ Family income } \\
\hline \multicolumn{7}{|c|}{ (times minimum wage) * } \\
\hline$>2.0$ & 1,530 & 0.33 & $0.12-0.81$ & 1.00 & & \\
\hline$\leq 2.0$ & 1,659 & 0.78 & $0.44-1.37$ & 2.41 & $0.80-8.65$ & 0.067 \\
\hline
\end{tabular}

* Monthly minimum wage at the time of our survey $=$ US\$ 50.00 (approx.). 


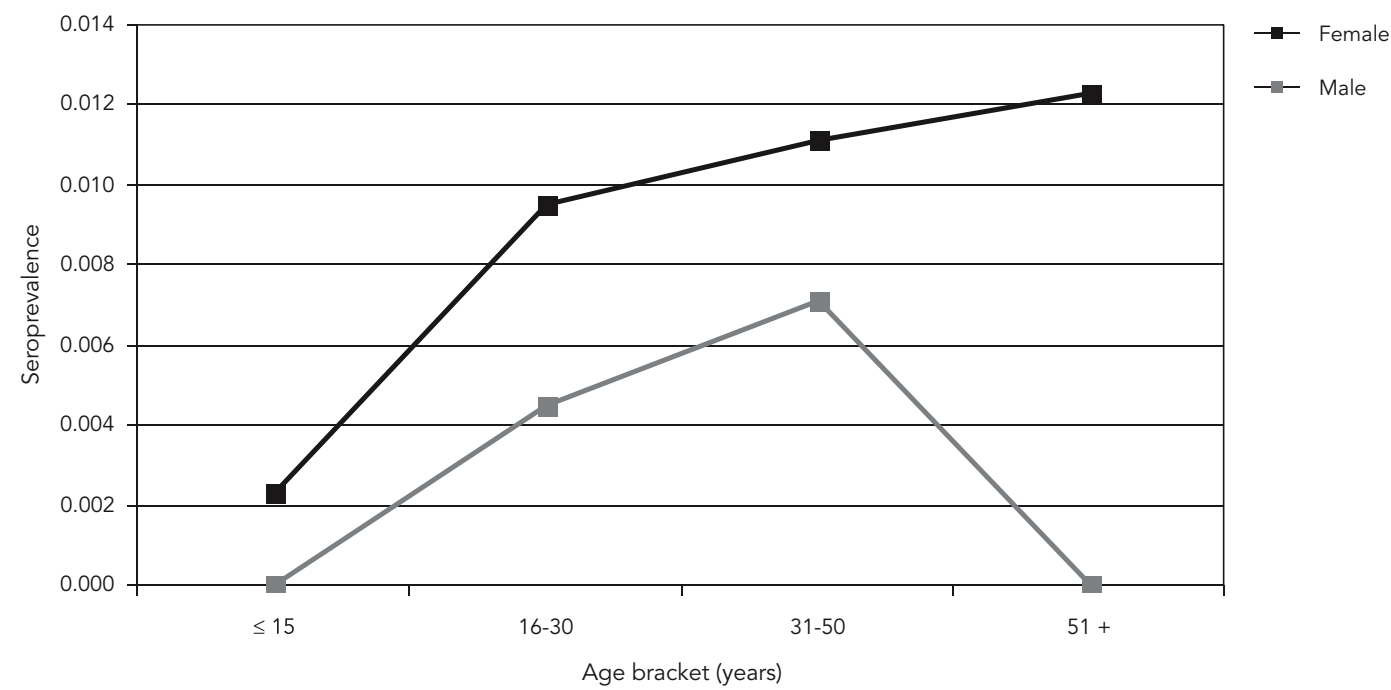

Multiple logistic regression analysis of risk factors for human immunodeficiency virus type (HIV-1) infection. Salvador, Bahia, Brazil, 1998-2000.

\begin{tabular}{lccc}
\hline Variables & OR & $95 \% \mathrm{Cl}$ & $95 \% \mathrm{Cl}$ * \\
\hline Age $(\geq 30$ years) & 3.27 & $1.21-8.81$ & $1.27-8.38$ \\
Gender (male) & 2.90 & $1.08-7.81$ & $1.01-8.35$ \\
Family income $\left(\leq 2.0\right.$ minimum wage) ${ }^{* *}$ & 2.60 & $0.92-7.36$ & $0.82-8.18$ \\
\hline
\end{tabular}

* Confidence interval adjusting for the cluster effect of the sample scheme Pearson's chi-square for model goodness-of-fit: $\chi 2=12.83 ; p=0.005 ;$ log likelihood $=-104.55 ;$ pseudo adjusted $R^{2}=0.058$.

$\star \star$ Monthly minimum wage at the time of our survey $=$ US $\$ 50.00$ (approx.).

(0.8\%) was 3.3 times greater than in the same age range in three cross-sectional samples from prenatal clinic attendees in Northeast Brazil in 1998 ( $0.24 \%$ overall; $0.33 \%$ for men and $0.15 \%$ for women) 7 . However, direct comparisons cannot be made, since the regional estimate represents a weighted average of infection rates for each State in the region, which vary considerably by State. In addition, studies have identified potential biases in inferring general population HIV prevalence from samples of prenatal clinic users 23 , since access to such clinics can vary ac- cording to several factors likely to be associated with HIV infection, such as age, socioeconomic status, education, parity, and others 24 . Several studies in Africa comparing HIV prevalence rates in prenatal clinics and the general population have shown a tendency for prenatal clinic surveillance samples to underestimate infection rates 25,26. However, a nine-year study in Tanzania showed similar prevalence in the two samples (prenatal clinic and general population) 27 .

The observed increase in prevalence with age was more marked in men than in women, 
probably a combined result of the age effect and the greater risk of infection among men. Another possible explanation would be a combination of a period, cohort, and age effect. Indeed, the higher proportion of infection among older groups might also reflect past infection during times of greater risk (cohort effect) 28 .

At the beginning of the AIDS epidemic in Brazil, most cases had more education. However, since 1995, national AIDS surveillance has identified a tendency towards increased incidence in poorer, less-educated groups, a phenomenon known in Brazil as "pauperization" of the epidemic 4,5,29. Our study showed higher HIV prevalence among individuals with lower income, in agreement with this recent profile of the AIDS epidemic in the country.

The multiple logistic regression model appeared to be well-specified; however, the low pseudo- $\mathrm{R}^{2}$ suggests that other known risk factors for HIV-1 infection which were not measured here (e.g. number of sexual partners, history of injecting drug use etc.) could also be important risk factors in this population.

We can speculate that the majority of HIVpositive individuals were infected via sexual

\section{Resumo}

A seroprevalência do HIV-1 na população geral de Salvador, Bahia, Brasil, foi estimada em estudo de corte transversal com 3.437 indivíduos entre 19982000, residentes de 30 áreas sentinelas com ampla variedade de condições de vida. Realizou-se uma triagem para anticorpos anti-HIV-1 por ELISA e confirmados por imunofluorescência. A determinação do subtipo foi realizada por HMA, após amplificação do DNA proviral. As análises filogenéticas foram realizadas com PAUP utilizando os algoritmos neighbor-joining. A seroprevalência do HIV-1 foi de 0,55\% (19/3.446): $0,8 \%$ para os homens e $0,36 \%$ para as mulheres. A seroprevalência foi mais alta no grupo de 31-45 anos (1\%) e entre as pessoas com renda familiar inferior a dois salários mínimos $(0,78 \%)$. A sífilis foi diagnosticada em $37 \%$ dos participantes HIV soropositivos. A análise filogenética identificou 10 amostras como subtipo B na região env, e duas amostras Benv/Fgag/Fpol e Fenv/Bgag. Idade $\geq 30$ anos, sexo masculino, renda $\leq 2$ salários mínimos se comportaram como fatores de riscos para a infecção por HIV-1. Se extrapolarmos a proporção de soropositivos para Salvador, o número de infectados pelo HIV seria 13.750.

HIV-1; Soroprevalência de HIV; Estudos Transversais transmission because syphilis seroreactivity was positive in $37 \%$, and because there is evidence of the decreased role of IDU and blood transmission in Brazil, especially among men ${ }^{3}$.

Molecular analysis of the HIV-1 samples isolated in our population indicated that the predominant subtype circulating in Salvador is still $\mathrm{B}$ (although recombinant $\mathrm{B}$ and $\mathrm{F}$ strains were also identified), and that the molecular profile identified here is consistent with previous subtype assessments in Salvador 9,10.

Extrapolation of our data to the entire city of Salvador would yield an estimated total of approximately 13,750 individuals [i.e. $(19 / 3,446) * 2,500,000]$ infected with HIV-1. However, this calculation should be viewed with caution, since the sentinel areas represent an approximation of the city of Salvador.

Finally, since Bahia State has the second highest AIDS incidence in Northeast Brazil, it is crucial to continue to monitor the molecular and demographic profile/evolution of the epidemic in order to design, evaluate, and maintain appropriate control measures.

\section{Contributors}

I. Dourado and B. Galvão-Castro provided the original idea for the article. M. G. Teixeira and M. L. Barreto were responsible for the study design and data collection. M. A. G. Mello, G. A. Ferraro, M. L. Guimarães, and M. G. Morgado conducted the laboratory tests. C. A. Milroy and H. Castro-Lima Filho contributed with the statistical analyses. All the authors participated in writing and reviewing the article.

\section{Acknowledgments}

The authors wish to thank Noilson Lázaro de Souza Gonçalves for his technical assistance. The research was partially supported by the National AIDS Program/Brazilian Ministry of Health, Bahia State Research Foundation, and Conselho Nacional de Desenvolvimento Científico e Tecnológico (CNPq). 


\section{References}

1. Centers for Disease Control and Prevention. Pneumocystis pneumonia - Los Angeles. MMWR Morb Mortal Wkly Rep 1981; 30:250-2.

2. Barre-Sinoussi F, Chermann JC, Rey F, Nugeyre MT, Chamaret S, Gruest J, et al. Isolation of a T-lymphotropic retrovirus from a patient at risk for acquired immune deficiency syndrome (AIDS). Science $1983 ; 220: 868-71$.

3. Ministério da Saúde. Boletim Epidemiológico AIDST 2004; Ano I, n. 1.

4. Fonseca MGP, Szwarcwald CL, Bastos FI. Análise sociodemográfica da epidemia de Aids no Brasil, 1989-1997. Rev Saúde Pública 2002; 36:678-85.

5. Fonseca MGP, Travassos C, Bastos FI, Silva NV, Szwarcwald CL. Distribuição social da AIDS no Brasil, segundo participação no mercado de trabalho, ocupação e status sócio-econômico dos casos de 1987-1998. Cad Saúde Pública 2003; 19:1351-63.

6. Szwarcwald CL, Bastos FI, Esteves MAP, Andrade CLT. A disseminação da epidemia de AIDS no Brasil, no período de 1987-1996: uma análise espacial. Cad Saúde Pública 2000; 16 Suppl 1:7-19.

7. Szwarcwald CL, Castilho EA. Estimativa do número de pessoas de 15 a 49 anos infectadas pelo HIV, Brasil, 1998. Cad Saúde Pública 2000; 16 Suppl $1: 135-41$

8. Ivo-dos-Santos J, Couto-Fernandez JC, Santana AJ, Luna TM, Cunha GC, Moreira L, et al. Prevalence of HIV-1 antibodies in selected groups of a Brazilian city with African sociodemographic characteristics. J Acquir Immune Defic Syndr 1991; 4:448-9.

9. Morgado MG, Guimarães ML, Galvão-Castro B. HIV-1 polymorphism: a challenge for vaccine development - a review. Mem Inst Oswaldo Cruz 2002; 97:143-50.

10. Couto-Fernandez JC, Morgado MG, Bongertz V, Tanuri A, Andrade T, Brites C, et al. HIV-1 subtyping in Salvador, Bahia, Brazil: a city with African sociodemographic characteristics. J Acquir Immune Defic Syndr 1999; 22:288-93.

11. Teixeira MG, Barreto ML, Costa MCN, Strina A, Martins Jr. D, Prado M. Sentinel areas: a monitoring strategy in public health. Cad Saúde Pública 2002; 18:1189-95.

12. Cochran WG. Sampling techniques. $3^{\text {rd }}$ Ed. New York: John Wiley \& Sons; 1977.

13. Instituto Brasileiro de Geografia e Estatística. Contagem da população - 1996. Rio de Janeiro: Instituto Brasileiro de Geografia e Estatística; 1997.

14. Heyndrickx L, Janssens W, Zekeng L, Musonda R, Anagonou S, van der Auwera G, et al. Simplified strategy for detection of recombinant human immunodeficiency virus type 1 group $\mathrm{M}$ isolates by gag/env heteroduplex mobility assay. Study Group on Heterogeneity of HIV Epidemics in African Cities. J Virol 2000; 74:363-70.
15. Morgado MG, Guimarães ML, Neves Jr. I, Velosodos-Santos VG, Linhares-de-Carvalho MI, Castello-Branco LR, et al. Molecular epidemiology of HIV in Brazil: polymorphism of the antigenically distinct HIV-1 B subtype strains. Mem Inst Oswaldo Cruz 1998; 93:383-6.

16. Morgado MG, Guimaraes ML, Gripp CB, Costa CI, Neves Jr. I, Veloso-dos-Santos VG, et al. Molecular epidemiology of HIV-1 in Brazil: high prevalence of HIV-1 subtype B and identification of an HIV-1 subtype D infection in the city of Rio de Janeiro, Brazil. Evandro Chagas Hospital AIDS Clinical Research Group. J Acquir Immune Defic Syndr Hum Retrovirol 1998; 18:488-94.

17. Janini LM, Pieniazek D, Peralta JM, Schechter M, Tanuri A, Vicente AC, et al. Identification of single and dual infections with distinct subtypes of human immunodeficiency virus type 1 by using restriction fragment length polymorphism analysis. Virus Genes 1996; 13:69-81.

18. Thompson JD, Gibson TJ, Plewniak F, Jeanmougin F, Higgins DG. The CLUSTAL_X windows interface: flexible strategies for multiple sequence alignment aided by quality analysis tools. Nucleic Acids Res 1997; 25:4876-82.

19. Kleinbaum DG, Kupper LL, Morgenstern H. Epidemiologic research: principles and quantitative methods. New York: van Nostrand Reinhold Company; 1982.

20. World Bank. Confronting AIDS: public priorities in a global epidemic. Washington DC: Oxford University Press; 1997.

21. Andrade TM, Dourado I, Galvão-Castro B. Associations among HTLV-I, HTLV-II and HIV in injecting drug users in Salvador, Brazil. J Acquir Immune Defic Syndr Hum Retrovirol 1998; 18:186-7.

22. Prado MS, Barreto ML, Strina A, Faria JAS, Nobre1 AA, Jesus SR. Prevalência e intensidade da infecção por parasitas intestinais em crianças na idade escolar na Cidade de Salvador (Bahia, Brasil). Rev Soc Bras Med Trop 2001; 34:99-101.

23. Fylkesnes K, Ndhlovu Z, Kasumba K, Musonda RM, Sichone M. Studying dynamics of the HIV epidemic population-based data compared with sentinel surveillance in Zambia. AIDS 1998; 12:1227-34.

24. Glynn JR, Buve A, Carael M, Musonda RM, Kahindo M, Macauley I, et al. Factors influencing the difference in HIV prevalence between antenatal clinic and general population in sub-Saharan Africa. AIDS 2001; 15:1717-25.

25. Changalucha J, Grosskurth H, Mwita W, Todd J, Ross D, Mayaud P, et al. Comparison of HIV prevalences in community-based and antenatal clinic survey in rural Mwanza, Tanzania. AIDS 2002; 16:661-5. 
26. Crampin AC, Glynn JR, Ngwira BM, Mwaungulu FD, Ponnighaus JM, Warndorff DK, et al. Trends and measurement of HIV prevalence in northern Malawi. AIDS 2003; 17:1817-25.

27. Kwesigabo G, Killewo JZ, Urassa W, Mbena E, Mhalu F, Lugalla JL, et al. Monitoring of HIV-1 infection prevalence and trends in the general population using pregnant women as a sentinel population: 9 years experience from Kagera region of Tanzania. J Acquir Immune Defic Syndr 2000; 23:410-7.
28. Ueda K, Kusuhara K, Tokugawa K, Miyazaki C, Yoshida C, Tokumura K, et al. Cohort effect on HTLVI seroprevalence in southern Japan. Lancet 1989; 2:979.

29. Grangeiro A. O perfil sócio-econômico dos casos de AIDS da cidade de São Paulo. In: Parker R, Bastos C, Galvão J, Pedrosa JS, organizadores. Aids no Brasil. Rio de Janeiro: Associação Brasileira Interdisciplinar de AIDS/Relume-Dumará; 1994. p. 91-125.

Submitted on 22/Nov/2005

Final version resubmitted on 28/Apr/2006

Approved on 19/May/2006 